\title{
Manfaat Kesehatan Tanaman Pala (Myristica fragrans) (Health Benefits of Nutmeg (Myristica fragrans ))
}

\author{
Lisna Rosalia Agaus ${ }^{1}$, Reski Vinalia Agaus ${ }^{2}$ \\ ${ }^{1}$ Puskesmas Waode Buri, Kabupaten Buton Utara \\ ${ }^{2}$ Fakultas Kedokteran, Universitas Haluoleo, Kota Kendari \\ Corresponding Author e-mail: lisna.raffaza@gmail.com
}

\begin{abstract}
ABSTRAK
Latar Belakang: Myristica fragrans merupakan sejenis rempah yang ditemukan di Kepulauan Indonesia, yang sebelumnya dikenal sebagai pulau rempah-rempah. Tanaman pala merupakan salah satu rempah yang memiliki harga tinggi yang sejak dahulu kala karena berbau sedap, menarik, dan berkhasiat untuk kesehatan. Sejak zaman kuno, pala telah digunakan sebagai obat untuk berbagai penyakit atau untuk meningkatkan kesehatan.Tujuan: Meskipun pala sudah dikenal sebagai rempah serbaguna, namun khasiatnya dalam pengobatan dan nilai terapi masih belum diketahui banyak orang.Sehingga tujuan penelitian ini yaitu untuk memperjelas manfaat kesehatan tanaman pala. Metode Penelitian: Penelitian dilakukan dengan metode deskriptif. Hasil: Manfaat kesehatan pala antara lain digunakan sebagai obat pencahar, pereda nyeri perut dan kontraksi usus, nyeri kepala, diare, mual, muntah, demam, bau mulut, merangsang nafsu makan dan mengatasi perut kembung. Pala juga berguna sebagai stimulan dan anti inflamasi. Penelitian juga menunjukkan bahwa pala dapat membantu menurunkan tekanan darah dan meredakan nyeri perut serta menghentikan diare dan (dalam dosis rendah) membantu mendetoksifikasi tubuh, dan merangsang otak. Simpulan: Tanaman pala memiliki banyak kesehatan olehnya itu bisa diolah menjadi salah satu produk herbal yang mudah dijangkau masyarakat.
\end{abstract}

\section{Kata Kunci: Manfaat Kesehatan Pala, Pala}

\section{ABSTRACT}

Introduction: Myristica fragrans has its origins in the Spice Islands of Indonesia, formerly known as the spice islands. Fragrant rich nutmeg is one of the highly prized spices known since antiquity for its aromatic, aphrodisiac, and curative properties. Since ancient times, nutmeg has been used as a remedy for various ailments or to improve health in general. Purpose: Although the culinary value of this magical spice is well-known, its medicinal and therapeutic values are mostly unheard of. So that, the purpose of this research is to clarify the health benefits of nut meg. Methode: This research is an descriptive research. Result: Health benefits nutmeg is used as a stomachic, stimulant, carminative as well as for intestinal catarrh and colic, headaches, diarrhea, vomiting, nausea, fever, bad breath, to stimulate appetites and to control flatulence. It is also valuable for its aphrodisiac and antiinflammatory properties. Studies show that it can help lower blood pressure and sooth a stomach ache as well as stop diarrhea and (in low dose) help to detoxify the body, stimulate the brain.Conclusion: Nut meg have many health benefits so nut meg must be processed to be a good herbal product which is easilya acessible to the public.

Keywords: Health benefits, nutmeg 


\section{PENDAHULUAN}

Negara Indonesia merupakan daerah tropis yang kaya raya akan jenis tumbuhtumbuhan yang beraneka ragam bentuk dan kegunaannya salah satunya sebagai tanaman obat. Jenis tanaman yang termasuk dalam kelompok tanaman obat mencapai lebih dari 1000 jenis, salah satunya adalah tanaman pala (Myristica fragrans). Tanaman pala adalah milik asli Indonesia terutama di daerah Banda dan sekitarnya,serta Irian Jaya.

Tanaman pala dikenal sebagai tanaman rempah-rempah yang memiliki nilai ekonomis dan multiguna karena setiap bagian tanaman ini dapat dimanfaatkan dalam berbagi industri makanan dan minuman, obat-obatan, parfum dan kosmetik. Selain itu pala juga menghasilkan minyak yang digunakan sebagai obat-obatan untuk stimulus sistem jantung, diare, rematik, nyeri otot, sakit gigi, menghilangkan racun dalam hati, serta berbagai khasiat lainnya.

Pala sebagai salah satu tanaman obat perlu dikelola dan dimanfaatkan secara optimal guna mendukung peningkatan kesehatan masyarakat Indonesia.

\section{METODE PENELITIAN}

Penelitian dilakukan dengan metode deskriptif. Membandingkan semua hasil penelitian yang pernah dilakukan terkait kandungan pala terhadap kesehatan.

Tabel 1. Penelitian yang telah dilakukan terhadap Pala

\begin{tabular}{llll}
\hline No. & Tujuan & Objek & Hasil yang \\
& Penelitian & Penelitian & Diperoleh \\
\hline 1. & Pengujian & Mencit & Efek sedatif \\
& efek sedatif & & lebih besar \\
& infuse biji & & pada infus biji \\
& pala & & pala r 10\% \\
& & & dibanding \\
& & & infus biji pala \\
\hline
\end{tabular}

\begin{tabular}{|c|c|c|c|}
\hline & & & $\begin{array}{lr}5 \% & \\
\text { Dan } & \text { lebih } \\
\text { kurang } & 1 / 10 \\
\text { efek } & \\
\text { Klorpromazina } \\
0,05 \%\end{array}$ \\
\hline 2. & $\begin{array}{l}\text { Pengaruh } \\
\text { ekstrak pala } \\
\text { terhadap } \\
\text { relaksasi otot } \\
\text { polos pada } \\
\text { usus halus }\end{array}$ & Kelinci & $\begin{array}{l}\text { Ekstrak pala } \\
\text { mempunyai } \\
\text { efek relaksasi } \\
\text { terhadap usus } \\
\text { halus }\end{array}$ \\
\hline 3. & $\begin{array}{l}\text { Efek sedative } \\
\text { seduhan biji } \\
\text { pala }\end{array}$ & Mencit & $\begin{array}{l}\text { Ada perbedaan } \\
\text { yang nyata } \\
\text { sebelum dan } \\
\text { sesudah diberi } \\
\text { seduhan biji } \\
\text { pala pada } \\
\text { konsentrasi } \\
60 \% \text { dan } 80 \%\end{array}$ \\
\hline 4. & $\begin{array}{l}\text { Uji aktifitas } \\
\text { anti stress dan } \\
\text { sedatif biji } \\
\text { pala }\end{array}$ & $\begin{array}{l}\text { Mencit } \\
\text { jantan }\end{array}$ & $\begin{array}{l}\text { Mencit yang } \\
\text { stress ditandai } \\
\text { penurunan } \\
\text { bobot badan } \\
\text { bermakna } \\
(\mathrm{p}<0,05) \text { dan } \\
\text { pemberian } \\
\text { aromaterapi } \\
\text { selama } 2 \text { jam } \\
\text { menunjukkan } \\
\text { efek anti stress }\end{array}$ \\
\hline 5. & $\begin{array}{l}\text { Uji motilitas, } \\
\text { viabilitas } \\
\text { ekstrak biji } \\
\text { pala }\end{array}$ & $\begin{array}{l}\text { Mencit } \\
\text { jantan }\end{array}$ & $\begin{array}{l}\text { Pemberian } \\
\text { ekstrak biji } \\
\text { paa dapat } \\
\text { meningkat-kan } \\
\text { motilitas, } \\
\text { viabilitas dan } \\
\text { konsentrasi } \\
\text { tetapi tidak } \\
\text { berpengaruh } \\
\text { terhadap } \\
\text { morfologi } \\
\text { normal } \\
\text { spermatozoa } \\
\text { mencit }\end{array}$ \\
\hline 6. & $\begin{array}{l}\text { Pala sebagai } \\
\text { sumber } \\
\text { Fenolik }\end{array}$ & Daun pala & $\begin{array}{l}\text { Kadar fenolik } \\
\text { total ekstrak } \\
\text { daun pala } \\
\text { sebesar } \\
183,56 \\
\text { mgGAE/g }\end{array}$ \\
\hline
\end{tabular}




\begin{tabular}{|c|c|c|c|}
\hline 7. & $\begin{array}{l}\text { Daya Hambat } \\
\text { Ekstrak Biji } \\
\text { Pala terhadap } \\
\text { Pertumbuhan } \\
\text { Bakteri } \\
\text { Escherichia } \\
\text { coli Secara In } \\
\text { Vitro }\end{array}$ & $\begin{array}{l}\text { Bakteri } E \text {. } \\
\text { coli }\end{array}$ & $\begin{array}{l}\text { Ekstrak biji } \\
\text { pala } \\
\text { menunjukkan } \\
\text { daya hambat } \\
\text { terhadap } \\
\text { pertumbuhan } \\
\text { bakteri } \\
\text { Escherichia } \\
\text { coli secara in } \\
\text { vitro. }\end{array}$ \\
\hline 8. & $\begin{array}{l}\text { Pengaruh } \\
\text { Konsentrasi } \\
\text { Ekstrak } \\
\text { Etanol Buah } \\
\text { Pala } \\
\text { Terhadap } \\
\text { Daya Hambat } \\
\text { Staphylo- } \\
\text { coccus aureus }\end{array}$ & $\begin{array}{l}\text { Bakteri } S . \\
\text { aureus }\end{array}$ & $\begin{array}{l}\text { Semakin besar } \\
\text { konsentrasi } \\
\text { yang diberikan } \\
\text { maka semakin } \\
\text { besar daya } \\
\text { hambat } \\
\text { terhadap } S \text {. } \\
\text { aureus }\end{array}$ \\
\hline 9. & $\begin{array}{l}\text { Uji Aktivitas } \\
\text { Repelan } \\
\text { terhadap } \\
\text { Nyamuk } \\
\text { Aedes aegypti } \\
\text { Betina } \\
\text { Sediaan } \\
\text { Emulgel } \\
\text { Minyak Atsiri } \\
\text { Biji Pala }\end{array}$ & $\begin{array}{l}\text { Nyamuk } \\
\text { Aedes } \\
\text { aegypti }\end{array}$ & $\begin{array}{l}\text { Peningkatan } \\
\text { konsentrasi } \\
\text { minyak atsiri } \\
\text { biji pala akan } \\
\text { mempercepat } \\
\text { daya lekat (p < } \\
0,05 \text { ) dan } \\
\text { meningkat- } \\
\text { kan efek } \\
\text { repelan (p < } \\
0,05)\end{array}$ \\
\hline
\end{tabular}

(Sumber data: Jurnal Kefarmasian Indonesia)

\section{HASIL}

Daging buah pala mengandung beberapa nutrisi seperti lemak dan protein nabati. Menurut penelitian yang telah dilakukan oleh Marzuki dkk.(2008) menyebutkan bahwa ditemukan kandungan lemak serta protein dalam daging buah pala. Selain itu pula, juga adanya pektin yang merupakan senyawa fenolik yang dikeluarkan oleh buah dalam bentuk getah yang berwarna merah kecoklatan.
Tabel 2. Kandungan Gizi Pala

\begin{tabular}{lll}
\hline Kandungan & Jumlah Gizi & Persentase \\
Gizi Pala per & & RDA \\
100 gram & &
\end{tabular}

\begin{tabular}{lll}
\hline Energi & $525 \mathrm{Kcal}$ & 26 \\
Karbohidrat & $49,29 \mathrm{~g}$ & $38 \%$ \\
Protein & $5,84 \mathrm{~g}$ & $10 \%$ \\
Lemak Total & $36,31 \mathrm{~g}$ & $180 \%$ \\
Kolesterol & $0 \mathrm{mg}$ & $0 \%$ \\
Diet Serat & $20,8 \mathrm{~g}$ & $55 \%$ \\
Folat & $76 \mu \mathrm{g}$ & $19 \%$ \\
Niacin & $1,299 \mathrm{mg}$ & $8 \%$
\end{tabular}

$\begin{array}{lll}\text { Pyridoxine } & 0,160 \mathrm{mg} & 12 \% \\ \text { Riboflavin } & 0,057 \mathrm{mg} & 4 \%\end{array}$

$\begin{array}{lll}\text { Tiamin } & 0,346 \mathrm{mg} & 29 \% \\ \text { Vit.A } & 102 \mathrm{IU} & 3,5 \%\end{array}$

\begin{tabular}{|lll} 
Vit. C & $3 \mathrm{mg}$ & $5 \%$ \\
\hline Sodium & $16 \mathrm{mg}$ & $1 \%$ \\
\hline
\end{tabular}

$\begin{array}{lll}\text { Potassium } & 350 \mathrm{mg} & 7,5 \% \\ \text { Calcium } & 184 \mathrm{mg} & 18 \% \\ \text { Copper } & 1.027 \mathrm{mg} & 114 \% \\ \text { Iron } & 3,04 \mathrm{mg} & 38 \%\end{array}$

$\begin{array}{lll}\text { Magnesium } & 183 \mathrm{mg} & 46 \% \\ \text { Manganese } & 2.900 \mathrm{mg} & 126 \% \\ \text { Phosporus } & 213 \mathrm{mg} & 30 \% \\ \text { Zink } & 215 \mathrm{mg} & 20 \%\end{array}$

\begin{tabular}{lll}
$\boldsymbol{\beta}$-Caroten & $16 \mu \mathrm{g}$ & - \\
$\begin{array}{l}\boldsymbol{\beta}-\text { Crypto- } \\
\text { xanthin }\end{array}$ & $90 \mu \mathrm{g}$ & -- \\
\hline
\end{tabular}

(Sumber Data : Jurnal Scientia Agriculturae) 


\section{PEMBAHASAN}

Menurut Okukpe et al (2012) komposisi kimia pada tanaman buah pala yaitu antara lain, flavonoid $1,37 \%$, oxalate $22,14 \mathrm{mg}$, saponin 49,32\% alkaloid 8,42\% dan phytate $16,00 \%$. Kandungan aktif yang terdapa dalam buah pala yaitu, mineral, Vitamin A, Vitamin B, vitamin C, asam folat, riboflavin, niasin, dan banyak flavonoid (Drazat,2007). Kandungan buah pala yang menunjukkan aktivitas antifungi yaitu Flavonoid, saponin dan alkaloid. Flavonoid sebagai senyawa antijamur bekerja dengan mengganggu permeabilitas membrane sel jamur dan merubah komponen organic serta transport nutrisi yang akhirnya mengakibatkan adanya efek toksik pada jamur (Jupriadi, 2011).

Menurut Sutomo (2006), kebiasaan menggunakan pala sebagai bumbu masakan atau mengkonsumsi dalam bentuk sirup dan manisan akan berdampak sangat baik bagi kesehatan, mengingat buah dengan keharuman semerbak ini ternyata mempunyai banyak khasiat bagi kesehatan. Kandungan kimia terkandung dapat mengatasi insomnia, batuk berlendir, membantu pencernaan, penghilang kejang otot dan lainnya.

Berdasarkan hasil riset penelitian yang dilakukan National Science and Technology Authority, dalam bukunya Guidebook on the proper use of medicinal plants. Buah pala mengandung senyawasenyawa kimia yang bermanfaat untuk kesehatan. Kulit dan daging buah pala misalnya, terkandung minyak atsiri dan zat samak. Sedangkan fuli atau bunga pala mengandung minyak atsiri, zat samak dan zat pati. Sedangkan dari bijinya sangat tinggi kandungan minyak atsiri, saponin, miristisin, elemisi, enzim lipase, pektin, lemonena dan asam oleanolat. Hampir semua bagian buah pala mengandung senyawa kimia yang bermanfaat bagi kesehatan, diantaranya dapat membantu mengobati masuk angin, insomnia (gangguan susah tidur), bersifat stomakik (memperlancar pencernaan dan meningkatkan selera makan), karminatif (memperlancar buang angin), antiemetik (mengatasi rasa mual mau muntah), nyeri haid serta rematik (Sutomo, 2006).

Sebagai obat, biji pala bersifat karminatif, stomakik, stimulan, spasmolitik dan antiemetik atau antimual (Weil, 1966). Minyak pala juga digunakan dalam industri obat-obatan sebagai obat sakit perut, diare dan bronchitis. Minyak ini memiliki kemampuan dapat mematikan serangga (insektisidal), anti jamur (fungisidal), dan anti bakteri. Selain itu minyak pala dapat dimanfaatkan dalam pembuatan salep untuk menghilangkan "rasa sakit" (salep gosok atau analgesic ointments), atau ramuan tonikum. Salep yang mengandung parutan biji pala, dapat mengurangi penderitaan akibat batuk rejan. Jenis-jenis obat-obatan tertentu ditingkatkan aromanya dengan minyak pala.

Bunga pala yang kering diseduh dengan ar hangat, kemudian diminum sebagai jamu pendorong keluarnya udara busuk alias kentut.

Selain itu aroma dari bunga pala mempunyai daya "sedative" alias penenang.

Buah pala berguna untuk mengurangi flatulensi, meningkatkan daya cerna, mengobati diare dan mual. Selain itu juga desentri, maag, menghentikan muntah, mules perut kembung serta obat rematik. Senyawa aroma myristicin, elimicin, dan safrole sebesar 2\%-18\% yang terdapat pada biji dan bunga pala 
merangsang halusinasi. Komponen myristicin dalam daging buah pala dapat menimbulkan rasa kantuk. Fuli pada buah pala juga menunjukkan adanya aktivitas antijamur dan bakteri yang kuat (Singh et al. 2005).

Komponen pala yaitu eugenol banyak digunakan dalam ilmu kedokteran gigi sebagai sealer saluran akar, dilaporkan eugenol menunjukkan aktivitas antibakteri terhadap bakteri oral (Lai et al. 2001). Evaluasi terhadap karakteristik anti oksidan biji pala telah diteliti oleh Jukic et al, hasil penelitian menunjukkan bahwa minyak atsiri biji pala mempunyai sifat antioksidan yang kuat. Aktivitas antioksidan tersebut disebabkan sinergisme diantara komponen-komponen minyak atsiri tersebut. Berdasarkan penelitian Rismundar (1990), komponen utama pala dan fuli yaitu myristicin dan elemicin dalam aromaterapi bersifat menghilangkan stress. Weiss E.A. menyebutkan bahwa senyawa aromatik myristicin dan elimicin sebesar $2-18 \%$ yang terdapat pada biji pala bersifat merangsang tidur.

\section{SIMPULAN}

Tanaman pala memiliki banyak manfaat kesehatan yang bila dikelola dengan baik dapat meningkatkan kesehatan masyarakat dan mendukung tujuan Negara kita yaitu mencapai Indonesia Sehat. Manfaat kesehatan pala antara lain digunakan sebagai obat pencahar, pereda nyeri perut dan kontraksi usus, nyeri kepala, diare, mual, muntah, demam, bau mulut, merangsang nafsu makan, mengatasi perut kembung, merangsang tidur, anti rematik, serta obat stress.

\section{SARAN}

Bagi penelitian selanjutnya diharapkan dapat melakukan penelitian eksperimental khususnya terkait manfaat pala untuk kesehatan organ tubuh manusia. Selain itu perlu dilakukan penyebarluasan informasi mengenai manfaat kesehatan dari tanaman pala bagi masyarakat.

\section{DAFTAR PUSTAKA}

Drazat. 2007. Meraup LAba dari Pala. Agromedia Pustala. Jakarta Selatan.

Jupriadi, L. 2011. Uji Aktivitas Ekstrak Etanol

Daun Waru (Hibicustilaceus L.) terhadap Jamur Malassezia furfur. Skripsi. Malang: Program Studi Kedokteran Hewan, Universitas Brawijaya Malang.

Lai, et.all. 2001. Antimicrobial activity of four root cana sealer against endodontic pathogens. Clin Oral Investig. 5:236-9.

Marzuki I, M.R Uluputty, A.A Sandr dan S. Memen. Karakteristik morfoekotipe dan proksimat pala Banda (Myristica fragrans Houtt). Bul. Agron.36(2): 145151.

Okukpe KM, Adeloye MA, Alli OI, Adeyina OA, Annongu A. Investigation of pytohormonal potential of some selected tropical plants. Res j med plants. 2012; 6(6):425-432.

Singh A, Rao AR. Modulatory effect of areca nut on the action of mace (Myristica fragrans, Houtt) on the hepatic detoxification system in mice. Food Chem Toxicol. 1993:31:517-21.

Sutomo, B. 2006. Buah Pala Mengobati Gangguan Insomnia, Mual, dan MAsuk Angin. PT. Gramedia Pustaka Jakarta.

Weil, A.T. 1966. The use of Nutmeg as a Psychotropic Agent. Buletin on Narcotica, Issue 4-002. 